\title{
BOOKENDS OF OLD TESTAMENT ETHICS: THE FIRST AND TENTH COMMANDMENTS AND HUMAN DIGNITY
}

\author{
Hendrik Bosman \\ Old and New Testament \\ Stellenbosch University
}

\begin{abstract}
The final position of the tenth commandment might suggest that it is intended as the climactic statement of a series of 'ten words' and is linked to the first commandment to form an inclusio. While the first commandment insists that there is no other God and that this is rooted in an internal posture; so too the tenth commandment is opposed to an inner attitude of self-interest that could influence and precipitate actions that violate one of the preceding commandments.
\end{abstract}

Key words: Old Testament Ethics; Decalogue; First Commandment, Tenth Commandment

\section{Introduction}

While the first commandment insists that there is no other God and that this is rooted in an internal posture; so too the tenth commandment is opposed to an inner attitude of selfinterest that could influence and precipitate actions that violate one of the preceding commandments. The final position of the tenth commandment might also suggest that it is intended as the climactic statement of a series of 'ten words' and is linked to the first commandment to form an inclusio.

Recently Piet Naudé (2010:211) attempted to sketch the historical context for human dignity in Africa and came to the conclusion that the slave trade, colonialism, post-colonial 'mis-rule' and the creation of a global economic system, were the major historical forces that shaped Africa in the $21^{\text {st }}$ Century. Against the historical backdrop "the underlying question facing Africa is how to regain relative autonomy and initiative for a continent that lost its sense of self-worth over the last 500 years" and how to "overcome deep-seated Afro-pessimism?" (Naudé 2010:229).

In his reflection on the relevance of the Ten Commandments for human rights, Walter Harrelson (1997) argued that the Decalogue continues to have relevance and authority by shaping the life of the Jewish and Christian faith communities through its indication of ethical parameters. The shaping of these parameters should not result in "some rigid moralistic code but to become involved in response to the need for wholeness in human society as it now confronts us..." (Birch 1983:124).

It is quite problematic to presume that everyone will agree on what commandment one is referring to if you discuss the first and the tenth commandments. There are at least three approaches to the numbering of the commandments in the Decalogue (Kuntz 1999:256):

- From Philo, Josephus to modern Protestants accept the following numbering - (i) no other gods, (ii) prohibition of images, (iii) taking the name of God in vain, (iv) 
Sabbath, (v) honouring parents, (vi) killing, (vii) adultery, (viii) theft, (ix) false witness, (x) covetousness (Kuntz 1999:256).

- Roman Catholics and Lutherans follow Augustine by combining the commandments on no other gods and the prohibition of images (first \& second) and divide the commandment on covetousness (tenth) in two - probably due to the use of two verbs coveting.

- Traditional Jews consider the Prologue to be the first commandment and then combine prohibitions on other gods and images to be the second commandment.

This discussion of the Decalogue will presuppose the first option with regards to the numbering of the individual commandments. A possible explanation of the different order of the commandments when use is made of ethical pronouncements resembling the Ten Commandments in different parts of the Old Testament, is that the author in question "is quoting the Decalogue, and therefore uses a Chiasmus, as in many other biblical quotations" (Hoffman 2011:41).

Another issue that has to be clarified before the discussion of elements of the Decalogue commences is whether there is a hierarchical order amongst the 'ten words' (Rooker 2010:20-21). If the honour of God (first half) takes precedence to the benefit of the community (second half) the first and last commandments as bookends can hardly be of equal importance. My approach does not share this presupposition and will link up with the Rabbinic tradition that the Decalogue was intended to be of relevance for all people (Sarna 1991:108).

\section{Preface to the Decalogue}

It is clear that Exodus 20:1 emphasizes the fact that God spoke the following words or commandments directly to Israel and not through an intermediary like Moses, establishing its importance from the very beginning (Stuart 2006:445).

In both Exodus 20:2 and Deuteronomy 5:6 the Decalogue is introduced by the same preface or preamble that Zimmerli (1953:179-209) described as a 'self-introductory' formula in which the announcement (revelation?) of the names of God is qualified by a reference to the deliverance of Israel from Egypt described as the 'house of slavery' (Collins 1992:385):

Exodus 20:2

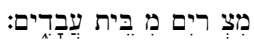

Exodus 20:2 = Deuteronomy 5:6 "I am the LORD your God, who brought you out of Egypt, out of the land of slavery".

According to the more theologically conservative (evangelical) interpretation the Prologue "identifies the God of the covenant and at the very outset presents the prime motives for obedience" - the Decalogue is introduced by the reminder of who the Lord God was: "your God' (due to the covenant?) and a gracious God who delivered Israel from slavery (Harman 1997:516).

The singular form of the address seems to presuppose individual Israelites and not necessarily the nation as a whole. It seems as if the Prologue establishes a relationship between the Lord and his people as individuals based on their salvation - this relationship is not the reward for any good deeds but an illustration of the mercy of God (Biddle 2003:107). 


\section{First Commandment}

The 'ethical Decalogue' (Ex 20 \& Deut 5) and the 'cultic Decalogue' (Ex 34) have three commandments in common: (i) no other gods, (ii) against making images, (iii) keeping the Sabbath - in each case the ethical version is more elaborate than the (older?) cultic version (Biddle 2003:105).

In a short and highly condensed manner, without any immediate explanation, the worship of other gods is prohibited. There may be a close link between the preamble and the first commandment if the self-introduction of 'the Lord your God' serves as an explanation or reason for the banning of foreign gods.

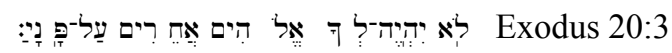

Exodus 20:3 = Deuteronomy 5:7 "You shall have no other gods before me."

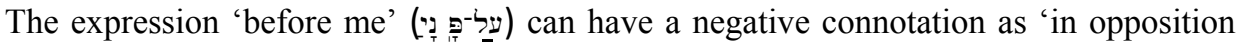
to', but here it seems as if a more positive reference to the exclusive relationship between the Lord and his people is intended. Whether the first commandment is a paradigmatic expression of monolatry, or even monotheism, needs further consideration since as it is formulated here "it can be understood within a henotheistic religious system" (Collins 1992:385). In any case the first commandment boils down to 'a description of a relationship' and not as 'a metaphysical or ontological statement' (Biddle 2003:108).

Dean McBride (2006:133-150) in his remarkable essay on the 'Essence of Orthodoxy' discusses the problems that emerge from the linking of the first commandment with monotheism: "The trouble with monotheism as a theological home is that it values abstraction over particularities, pure being over doing, inclusiveness over integrity" while the trouble with polytheism on the other hand boils down to "that it assigns independent divinity to powers and attributes that belong exclusively to the Lord and it deifies entities that the Lord created... or worse, confuses deity with things that are merely creations of human imagination and industry."

The Shema in Deuteronomy 6:4-9 is considered to be a "positive restatement and radicalization of the first commandment" that can be qualified as a comprehensive appeal for concrete "obedience to God with one's whole nepesh" because "the Shema does not call for interior, private or spiritual devotion"; on the contrary, the Shema constitutes a call to "love YHWH with all one's very life" (Biddle 2003:124-126).

The Africa Bible Commentary (2006:110) explains the first commandment as an injunction for monotheism in the light of the New Testament, "no one can serve two masters" (Matt 6:23), and then claims that this "truth is equally inscribed in African culture" by quoting two African proverbs:

- "A man cannot choose two roads at the same time" (Dogon of Mali).

- "One cannot chase two pigeons at once" (Beti of Cameroon).

Against the backdrop of the Prologue and the first commandment Benezet Bujo (1990:14) takes note of the claim that in Africa "everybody knew God even before the arrival of Christianity" and then responds with the challenge if this God is "really the Saviour revealed in the Old Testament...?" Bujo (1990:15) continues with the assurance that there is "no reason to abandon the veneration of the ancestors, but it must be seen in the light of God as revealed in Jesus Christ." 


\section{Tenth Commandment}

In his rhetorical study of the Decalogue Greenstein (2011:7) considers it both important and significant that the first half and the last commandment of the "ten words" are longer than those in the first half, with the exception of the tenth commandment.

The final commandment shifts the focus from 'outward actions' to 'inward motives' and it seems to presuppose that desire is the underlying reason for the preceding commandments. Therefore one might consider the possibility that the tenth commandment fulfills a summarizing rule (Harman 1997:518)

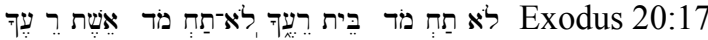

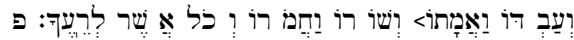

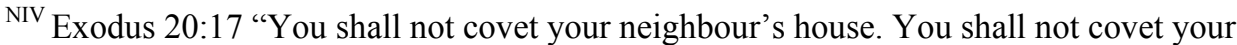
neighbour's wife, or his manservant or maidservant, his ox or donkey, or anything that belongs to your neighbour."

The second century Nash Papyrus has reversed the initial sequence (switching 'house' and "wife") and this sequence corresponds with the version in Deuteronomy 5:21, thereby illustrating the fluidity of text traditions, as well as the possible older provenance of the Decalogue in Deuteronomy. In the Samaritan Pentateuch a legitimation for Shechem instead of Jerusalem was added (Propp 2006:114).

One can well ask whether 'coveting' (חמר) is a punishable offense and how it links up with the preceding commandments. Herrmann (1927:69) argued that לא תַח מר refers to more than a mere inclination, but to 'the preparation for and attempt to carry out' the inclination (Houtman 2000:68).

Since then Biddle (2003:116) has determined that in order to have this meaning hmd must be accompanied by an additional verb denoting action (Deut 7:25; Josh 7:21; Mic 2:2). This might be the explanation why in Deuteronomy 5:21 ('desire, want') is used as a synonym for חמר

'House' does not refer in this instance to a physical structure but to an extended household comprising of many members such as wives, servants and even livestock - each having some economic value (Propp 2006:180).

The tenth commandment probably addresses the state of mind leading up to the breaking of the previous commandments (stealing, lying, committing adultery, etc). In this sense, the tenth commandment can be seen as being prior to each of the other commandments on the second table of the Decalogue.

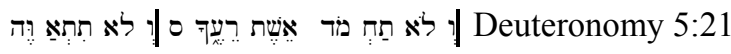

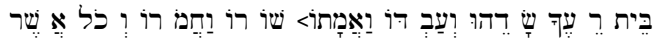

$$
\begin{aligned}
& \text { לרעיד: } 0
\end{aligned}
$$

Deuteronomy 5:21 "You shall not covet your neighbour's wife. You shall not set your desire on your neighbour's house or land, his manservant or maidservant, his ox or donkey, or anything that belongs to your neighbour."

The addition of 'land, field' (שדה) in 5:21 might suggest that 'house' in this instance does refer to a structure and not to the extended household (Houtman 2000:70). Deuteronomy makes the further distinction between the 'coveting' for a married or betrothed woman (חמר) and the 'desire' or 'longing' (אואה) for objects of economic or status value - house, field, slaves, livestock, etc (McConville 2002:130). 
The tenth commandment seems to be a final call for restraint on covetousness and desire, 'whether or not acted upon' (Miller 2009a:522). Smith (1991:227-230) is of the opinion that the last commandment is not a quiet conclusion of the collection of 'ten words' but that it forms the capstone for all of them. This opinion is the result of an argument for interpreting the Decalogue as a chiastic structure with the first and tenth commandment as the anchors for the whole.

Rene Girard (1992:185-207) provides an evocative description of the final commandment: "To prevent people from fighting, the lawgiver seeks at first to forbid all the objects about the ceaseless fight, and he decides to make a list of these. However, he quickly perceives that the objects are too numerous: he cannot enumerate all of them...he turns to that one who is always present, the neighbour. One always desires whatever belongs to that one, the neighbour." If we read the tenth commandment with the first commandment there is indeed another One who is always present and thus a fruitful theological-ethical dialectic develops between the only One at the beginning of the Decalogue and the neighbour as the other at the end.

According to Bujo (1990:81) earthly possessions in Africa "are objects of prestige and therefore the tenth commandment is quite relevant" because "the hunger for power among us Africans is motivated first and foremost by an unquenchable thirst for material possessions".

\section{Conclusion: Coherence in the Decalogue and Implications for Old Testament Ethics}

In Judaism the Decalogue is divided into two tablets with five commandments each where the first half all contains a reference to God and is concerned with the correct worship of the Lord; while the second half does not refer to God directly and refers to matters social and interpersonal (Kuntz 1999:256). These two sets of five commandments are also related in pairs and thus the first commandment and the introduction "I am the Lord your God" is linked with "You shall not murder"; while the "honour your father..." is linked with "you shall not covet your neighbour's wife".

It is significant that the Ten Commandments were recited with the Shema in the sacrificial service in the First Temple, but the rabbis of the Second Temple were very circumspect not to establish the impression that the Decalogue was more important than any of the other laws (b.Ber. 12a). During the Middle Ages the rabbis came to the decision that there were no less than 613 commandments in the Hebrew Bible and that 365 of them were negative (corresponding the number of days in the year) and 248 are positive commandments related to what was presupposed to be the number of parts of the human body (b.Mak 23b).

Following Augustine, the Roman Catholic Church distinguishes between the first three commandments on the love of God and the last seven on the love for the neighbour (Kuntz 1999:257).

Despite the current general acceptance of the importance of the Decalogue as a summary of the Old Testament Torah and a concise ethical blueprint for moral decision making, Rodd's (2001:86) sobering words of caution must be heeded: "The Ten Commandments... cannot be regarded as the fount of the Pentateuchal laws, still less of Old Testament ethics. Neither can they be seen as a summary of the teaching of the prophets, or as a succinct expression of the central principles of a wider ethics... the Decalogue needs to be examined on its own." This more qualified appreciation is echoed by 
Janzen (1994:91) in his paradigmatic approach to Old Testament Ethics: "the Decalogue... neither qualifies as a comprehensive summary of the content of ethics, nor was it intended and interpreted as such in the Old Testament."

Caution caused by uncritical presuppositions on the importance of the Decalogue in both the Old Testament and early Jewish tradition does not imply that it is not worthwhile considering the internal connectivity of the individual commandments. The reasons for the relative importance of the Ten Commandments in the books of Exodus and Deuteronomy are editorial concerns that fall beyond the scope of this particular discussion.

The final position of the tenth commandment might suggest that it was intended as the climactic statement of the series of 'ten words' and that it is linked to the first commandment to form an inclusio. While the first commandment insists that there is no other god, the close proximity to the Prologue suggests that it is rooted in an internal posture that determines one's relationship with God; so also the tenth commandment is aimed at an inner attitude of self-interest that could inspire actions that violate any of the preceding commandments - with special relevance for the last five linked to the relationship with other human beings. The Decalogue as 'ten words' or commandments should also be understood as a whole that generates both love and obedience towards the Lord their God, as well as love and service to the neighbour (Childs 1974:439).

Does the final position of the commandment against covetousness and desire reinterpret the preceding commandments? Does the prohibition of murder now include refraining from hate and aggression (those attitudes that might lead to murder); the prohibition against adultery might become the command to refrain from lust and the command not to steal will then be understood as an indictment of greed (Patrick 2006:778). According to Durham (1987:297-298) the covetousness prohibited by the last commandment can be interpreted as "the gateway to the violation of every other principle in the Decalogue" that functions as "a kind of summary commandment, the violation of which is a first step that can lead to the violation of any one or all the rest of the commandments”. Recently Hossfeld (2006:404) came to a similar conclusion: "Die Ausweitung des Verbots von der konkreten Tat auf alle Wünsche und Gedanken, die zu ihr hinführen, ist später... zum Hauptansatzpunkt der Gesinnungsethik geworden."

Patrick Miller (2009b:406) quotes Martin Luther in his discussion about the interconnectedness of the first and tenth commandments: „A man [sic] is generous because he trusts God and never doubts but that he will always have enough. In contrast a man is covetous and anxious because he does not trust God." Luther also comments on the interconnectedness of the first and last commandment in his well known Shorter Catechism: „We should fear and love God, that we may not desire by craftiness to gain possession of our neighbour's inheritance or home..." (Rooker 2010:174).

Living according to the Decalogue and its 'ten words' entail both heart and mind, as well as individual actions. In the words of Miller (2009a:522): "Careful observance of the whole is understood to manifest the true worship of the Lord and ensure both the wellbeing of the neighbor and the common good". Considering the first and tenth commandments as bookends of the Decalogue and of Old Testament ethics in general, might just serve this very purpose!?

To conclude: the Decalogue starts with the reminder in the Prologue who God is and with a first command to have no other gods, while the tenth commandment ends with the reference to the neighbour: "Between those two subjects lies the moral space of the Commandments", and I might add the creative tension required in the theological-ethical reflection on human dignity (Miller 2009b:406). 


\section{BIBLIOGRAPHY}

Adeyemo, T (general ed.) 2006. African Bible Commentary. Nairobi: Paulines.

Biddle, ME 2003. Deuteronomy (S\&H). Macon: Smyth \& Helwys.

Birch, BC 1983. Book review on "The Ten Commandments and Human Rights" by Walter Harrelson, JBL 102:123-124.

Bujo, B 1990. Do we still need the Ten Commandments? A fundamental question in today's Africam World. Nairobi: St Paul Publications.

Childs, BS 1974. Exodus. A commentary. London: SCM.

Collins, RF 1992. 'Ten Commandments', in DN Friedman (ed.), Anchor Bible Dictionary Volume 6. New York: Doubleday, 383-387.

De Villiers, E 2010. "The recognition of Human Dignity in Africa: a Christian ethics of Responsibility perspective." Scriptura 104:263-278.

Durham, JI 1987. Exodus (WBC 3). Waco: Word Books.

Girard, R 1992. 'Job as failed scapegoat', in L Perdue (ed.), Voice from the whirlwind. Nashville: Abingdon, 185-207.

Greenstein, EL 2011. 'The rhetoric of the Ten Commandment', in HG Reventlow \& Y Hoffman (eds.), The Decalogue in Jewish and Christian tradition. New York: T\&T Clark, 1-12.

Harman, AM 1997. 'Decalogue' (Ten Commandments), in WA vanGemeren (ed.), NIDOTTE 4, 513-519.

Harrelson, WJ 1997. The Ten Commandments and Human Rights. Macon: Mercer.

Herrmann, J 1927. 'Das zehnte Gebot', in Sellein Festschrift. Leipzig, 69-82.

Hoffman, Y 2011. "The status of the Decalogue in the Hebrew Bible", in HG Reventlow \& Y Hoffman (eds.), The Decalogue in Jewish and Christian tradition. New York: T\&T Clark, 32-49.

Hossfeld, FL 2006. 'Dekalog', in M Görg and B Lang (eds.), Neues Bibel Lexicon A-G. Stuttgart: Benzinger, 400-405.

Houtman, K 2000. Exodus Volume 2. Kampen: Kok.

Janzen W 1994. Old Testament Ethics. A Paradigmatic approach. Louisville: Westminster/John Knox.

Kuntz, PJ 1999. 'Decalogue', in JH Hayes (ed.) Dictionary of Biblical Interpretation A-J. Nashville: Abingdon, 256- 262.

Lehmann, PL 1995. The Decalogue and a Human Future. Grand Rapids: Eerdmans.

Marshall, JW 2003. 'Decalogue' in TD Alexander \& DW Baker (eds.), Dictionary of the Old Testament. Pentateuch. Downers Grove: InterVarsity Press, 171- 182.

McBride, SD 2006. "The Essence of Orthodoxy: Deuteronomy 5:6-10 and Exodus 20:2-6", Interpretation 60:133-150.

McConville, JG 2002. Deuteronomy (Apollos OT Commentary). Leicester: Apollos.

Meyers, C 2006. Exodus (CBC). Cambridge: CUP.

Miller, PD 2009a. 'Ten Commandments', in KD Sakenfeld (ed.), NIDB Volume 5, 517-522.

Miller, PD 2009b. The Ten Commandments. Louisville: Westminster/John Knox. 
Naudé, PJ 2010. "Human Dignity in Africa: Sketching the Historical Context." Scriptura 104:221-230.

Otto, E 2007. 'Decalogue. 1.Old Testament', in HD Betz et al (eds.), Religion Past and Present Volume 3. Leiden: Brill, 709-712.

Patrick, D 2006. 'Covet', in NIDB Volume 1. Nashville: Abingdon, 778.

Propp, WHC 2006. Exodus 19-40 (Anchor Bible). New York: Doubleday.

Rodd, CS 2001. Glimpses of a strange land. Studies in Old Testament Ethics. Edinburgh: T\&T Clark.

Rooker. MF 2010. The Ten Commandments. Ethics for the Twenty-First Century. Nashville: B\&H.

Saran, N 1991. Exodus (JPS Torah Commentary). Philadelphia: JPS.

Smith, L 1991. “Original Sin as 'Envy': The structure of the Biblical Decalogue,” Dialog 30:227 -230.

Stuart, DK 2006. Exodus (NAC 2). Nashville: Broadman \& Holman.

Vellem, V 2010. "SERITHI / ISIDIMA: Reflections on Human Dignity in South Africa from a Black African perspective." Scriptura 104:314-321.

Zimmerli, W 1953. 'Ich bin Jahwe', in G Ebeling (ed.), Geschichte und Alte Testament. Alt Festschrift (BHT 16). Tübingen: Mohr \& Siebeck, 179-209. 